Annals of Plant and Soil Research 23(3): 310-313 (2021)

https://doi.org/10.47815/apsr.2021.10075

\title{
Genetic variability studies in germplasm of wheat (Triticum aestivum L.)
}

\section{NISHANT PATIAL, GIDEON SYNREM, SHARAD PANDEY AND VIVEK SINGH}

\author{
Department of Agriculture (Genetics and Plant Breeding), Himgiri Zee University P.O. Sherpur, Chakrata Road, \\ Dehradun (Uttarakhand) \\ Received: April, 2021: Revised accepted: June, 2021
}

\begin{abstract}
In the present investigation, twenty genotypes of bread wheat (Triticuma estivum L.) were evaluated to examine the presence of genetic variability which may further be utilized in breeding programmes. The experiment was laid out in randomized block design with three replications at the experimental field of Himgiri Zee University, Dehradun during 2019 - 2020. Analysis of variance revealed that genotypes possessed significant genetic variability among all traits. It was observed that HUW-251 (recorded the highest value 67.33 g) where as HUW-213 exhibited the lowest value $(48.00 \mathrm{~g})$ for grain yield per plant. The highest estimates of genotypic coefficient of variation (GCV) and phenotypic coefficient of variation (PCV) were observed for spike weight(g) (19.97, 19.98) respectively, followed by flag leaf area (15.64) and spikelets per spike (14.49, 14.59). High heritability $\left(h^{2}\right)$ associated with high genetic advance as percent of mean (GAM) were observed for grain yield, test weight, grains per spike, spikelets per spike, spike weight, spike length, peduncle length and flag leaf area.
\end{abstract}

Keywords: Genetic advance, heritability, PCV, GCV, wheat

\section{INTRODUCTION}

Wheat (Triticum aestivum L.) is the most important cereal crop for the majority of world's population.India, being blessed and enriched with a diverse agro-ecological condition, ensuring food and nutrition security to a majority of the Indian population through production and steady supply particularly in the recent past, is the second largest producer of wheat worldwide. The crop has been under cultivation in about 30 million hectares (14\% of global area) to produce the all time highest output of 99.70 million tonnes of wheat $(13.64 \%$ of world production) with a record average productivity of $3371 \mathrm{~kg} / \mathrm{ha}$ as per 2017-18. For a successful breeding programme, presence of the genetic variability plays a vital role. With more diverse plants, greater chance to generate productive recombinant and broad variability in segregating generation during genetic improvement (Mohammadi and Parasana 2003). Genetic variability in a population can be partitioned into heritable and non-heritable variation with the aid of genetic parameters such as variance, genotypic coefficient of variation, heritability and genetic advance, which serves as a basis for selection of some outstanding genotypes from existing ones. Therefore, keeping in mind the above facts, the extent of genetic variability was investigated in twenty genotypes of bread wheat genotypes for various quantitative traits.

\section{MATERIALS AND METHODS}

The germplasm were evaluated at Himgiri Zee University, Dehradun during Rabi 2019-20. Dehradun is located at the foot of the Himalayas. It has an altitude of 960 meters $(2100 \mathrm{ft})$ above sea level with 30.31 degree north latitude and 78.03degree east longitude with annual average rainfall of $2073.3 \mathrm{~mm}$ mostly received during June to September. The annual average temperature of the study area is $20^{\circ} \mathrm{C}$ with maximum and minimum temperature of $27.8^{\circ} \mathrm{C}$ and $13.3^{\circ} \mathrm{C}$, respectively. The relative humidity is $76 \%$. The soil type classified is sandy loam soil with a pH of 7.20 and found under normal range. The experimental material consisted of 20 germplasm of bread wheat (Triticum aestivum L.) including two standard checks HUW-234 and RAJ 3765. The experiment was carried out in randomized block design (RBD) in 3 replications with 20 entries. The germplasm were grown under irrigated conditions. Each germplasm was sown in three rows of 1 meter length. Standard package of practices were followed to raise a good crop. Planting was done in furrow lines made by hand hoe on $6^{\text {th }}$ December 2019. Recommended 
fertilizer rate of 120: 80: 60 of N:P:K kg ha ${ }^{-1}$ was applied in the form of Urea, DAP and MOP. Nitrogen was applied in three split doses, first at the time of sowing, second at the time of first irrigation and third at the time of tillering. The observations recorded were five randomly selected plants were selected to record the data for 15 quantitative characters viz. Days to $50 \%$ flowering, Days to maturity, Plant height $(\mathrm{cm})$, Spike length $(\mathrm{cm})$, Spike weight $(\mathrm{g})$, Peduncle length $(\mathrm{cm}), 1000$ kernel weight of wheat $(\mathrm{g})$, Harvest index (\%),Biological yield (g), Grain yield per plant (g), Number of spikelet per spike, Flag leaf area $\left(\mathrm{cm}^{2}\right)$, Number of productive tillers per plant, Number of grain per spike, Grain filling period. While two characters viz., days to $50 \%$ flowering and days to maturity were recorded on plot basis. Statistical analysis of mean data over replications was subjected to analysis of variance as suggested by Panse and Sukhatme (1967). The phenotypic, genotypic and environmental variances were calculated according to the formula of Burton and de vane (1953).Broad sense heritability for all characters was estimated as the ratio of genotypic variance to the phenotypic variance and expressed in percentage according to the methods suggested by Falconer and Mackay (1996) Where, $\mathrm{H}^{2} \mathrm{~B}=$ heritability in broad sense Robinson et al. (1949) classified heritability values as High (>60\%), Moderate (30-60\%) andLow (0-30\%). The expected genetic advance expressed under selection in broad sense, assuming selection intensity of $5 \%$ of the superior progeny was estimated in accordance with the methodology described by Allard (1960). Genetic advance as percent of mean was calculated to compare the extent of predicted advance of different traits under selection, using the following formula Falconer and Mackay (1996).

\section{RESULTS AND DISCUSSION}

\section{Analysis of Variance (ANOVA)}

Mean squares of the 15 characters from analysis of variance (ANOVA) are presented in Table 1. Significant differences were observed among treatments for all characters studied. This indicated the presence of variability, which can be exploited through selection for further breeding programs.Similar work was done by Arya et al. (2017) revealedsignificant differences among wheat treatments during the study for the traits days to $50 \%$ flowering, plant height, peduncle length, number of productive tillers per plant, days to maturity, spike length, number of spikelets per spike, number of grains per spike, 1000-grain weight, biological yield per plant, grain yield per plant, harvest index and gluten content. Nishantet al. (2018), Kumari et al. (2020) and Upadhyay et al. (2020) also reported similar findings in their research work on bread wheat.

Table 1: Analysis of variance (ANOVA) of twenty wheat genotypes for fifteen characters

\begin{tabular}{|c|c|c|c|c|}
\hline \multirow{2}{*}{ Characters } & \multicolumn{3}{|c|}{ Mean sum of squares } & \multirow{2}{*}{ CV (\%) } \\
\hline & Treatment $(\mathrm{df}=19)$ & Replication $(\mathrm{df}=2)$ & Error $(\mathrm{df}=38)$ & \\
\hline Days to $50 \%$ flowering & $15.26^{* *}$ & 7.82 & 0.38 & 0.63 \\
\hline Days to maturity & $12.92^{* *}$ & 11.25 & 0.20 & 0.31 \\
\hline Plant height $(\mathrm{cm})$ & $213.97^{* *}$ & 1.40 & 0.01 & 0.08 \\
\hline Flag leaf area $\left(\mathrm{cm}^{2}\right)$ & $111.74^{\star *}$ & 6.29 & 0.00 & 0.07 \\
\hline Peduncle length $(\mathrm{cm})$ & $17.09^{* *}$ & 7.64 & 0.00 & 0.35 \\
\hline Grain filling period (days) & $32.47^{\star \star}$ & 14.07 & 0.31 & 1.29 \\
\hline Biological yield per plant $(\mathrm{g})$ & $30.68^{\star *}$ & 34.74 & 0.01 & 0.05 \\
\hline Harvest index (\%) & $21.04^{\star \star}$ & 4.48 & 0.00 & 0.04 \\
\hline Productive tillers per plant & $0.66^{\star *}$ & 28.80 & 0.17 & 12.44 \\
\hline Spike length $(\mathrm{cm})$ & $9.13^{* *}$ & 12.56 & 0.00 & 0.30 \\
\hline Spike weight (g) & $0.86^{\star *}$ & 18.45 & 0.00 & 0.56 \\
\hline Number of spikelets per spike & $33.47^{\star *}$ & 22.05 & 0.16 & 1.71 \\
\hline Number of grains per spike & $80.99^{\star *}$ & 84.05 & 0.16 & 0.75 \\
\hline Grain yield per plant (g) & $83.40^{* *}$ & 45.00 & 0.08 & 0.51 \\
\hline Test weight $(\mathrm{g})$ & $94.72^{\star \star}$ & 53.79 & 0.04 & 0.46 \\
\hline
\end{tabular}

$\overline{D F}=$ Degrees of freedom, ${ }^{*}=$ significant at $0.5 \%$ probability level and ${ }^{* *}=$ highly significant at $0.01 \%$ probabilitylevel, $C V=$ Coefficient of Variation 


\section{Phenotypic and genotypic coefficient of variation}

The PCV ranged from 1.48 for days to maturity to 19.98 for spike weight (Table 2). GCV ranged from 1.44 for days to maturityto 19.97 for spike weight. Phenotypic coefficients of variation were generally higher than genotypic coefficients of variation for all traits studied indicating the less influence of the environments on the characters studied. In most of the cases, the two values differ slightly indicating less influence of environmental factors. Burton and de-Vane (1953) classified PCV and GCV values as high (>20\%), medium (10-20\%) and low (<10\%). Accordingly, medium PCV and GCV were observed in traits like productive tillers per plant, peduncle length, test weight, spikelets per spike, flag leaf area and spike weight. The medium PCV and GCV indicate that selection may be effective based on these traits. In support of the experimental findings Arya et al. (2017), Upadhyay et al. (2020) also reported similar results.

\section{Estimates of Heritability $\left(\mathbf{H}^{2}\right)$ In Broad Sense}

In this study, the heritability estimate ranged from $49.47 \%$ for productive tillers per plantto $100 \%$ for flag leaf area (Table 2). Robinson et al. (1949) classified heritability values as high $(>60 \%)$, moderate $(30-60 \%)$ and values less than $10 \%$ low. Accordingly, high heritability was observed for fourteen characters of 20 bread wheat germplasm. High heritability values for these traits indicated that the variation observed was mainly under genetic control and was less influenced by the environment and the possibility of progress for selection. This may be attributed due to uniform environmental conditions during the conduct of the experiment. Indicating that the possibility of success in selection. The obtained results were well supported by similar findings of Upadhyay et al. 2020.

Table 2: Estimates of mean, range, variance components, coefficients of variability, heritability and genetic advance as percentage of mean for 15 characters of Wheat (Triticumaestivum L.)

\begin{tabular}{|c|c|c|c|c|c|c|c|c|c|c|c|}
\hline \multirow{2}{*}{ Characters } & \multirow[b]{2}{*}{ Mean } & \multirow{2}{*}{ SE \pm} & \multicolumn{2}{|c|}{ Range } & \multirow{2}{*}{$\mathrm{Vg}$} & \multirow{2}{*}{$V p$} & \multirow{2}{*}{$\begin{array}{c}\text { GCV } \\
(\%)\end{array}$} & \multirow{2}{*}{$\begin{array}{c}\text { PCV } \\
(\%)\end{array}$} & \multirow{2}{*}{$\begin{array}{c}\mathrm{h}^{2} \text { (b.s) } \\
\%\end{array}$} & \multirow{2}{*}{ GA } & \multirow{2}{*}{\begin{tabular}{|c|} 
GAM \\
$(\%)$
\end{tabular}} \\
\hline & & & Min & Max & & & & & & & \\
\hline Da) & 8 & 35 & 93.00 & 102 & 96 & 5.34 & 2.26 & 2.35 & 92.92 & 4.42 & 4.49 \\
\hline & & & 136.00 & & & & & 1.48 & & 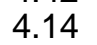 & \\
\hline & & & & 105 & & & & & 99.99 & 17. & \\
\hline & & & 29.01 & & & & 15.64 & 15 & 10 & & \\
\hline & 1 & & 13.35 & 22 & & & 13.04 & 13.05 & 99.93 & 4.91 & \\
\hline & 4 & & 37.00 & 50 & & & 7.55 & 7. & & & \\
\hline & & 0.05 & 156.69 & 166 & 10 & 10 & 1.9 & 1. & 99.93 & 6.58 & \\
\hline & & 001 & 29.95 & 40 & & & 7.63 & 7. & 100 & & \\
\hline & & 0. & & 4. & 0 . & & 12.30 & 17.49 & 49 & 88 & \\
\hline & 1 & & & & & & 994 & 9.9 & & & \\
\hline & 3 & & & & & & 19.97 & & & & \\
\hline & & & & & & & 14.48 & & & & \\
\hline & & & & & & & & & & & \\
\hline & & & & & & & & & & & \\
\hline Test weight (g) & & & 36.00 & & 31.56 & 31.60 & 13.30 & 13.31 & 99.88 & & \\
\hline
\end{tabular}

\section{Estimates of Expected Genetic Advance (GAM \%)}

Genetic advance expressed as a percentage of the mean ranged from 2.91 for days to maturity to 41.13 for spike weight. Falconer and Mackay (1996) classified genetic advance as percent of mean as low (0-10\%), medium (10 - 20\%) and high (20\% and above). Accordingly, genetic advance as percentage of mean was high for eight characters which includes Grain yield, grains per spike, spike length, peduncle length, test weight, spikelets per spike, flag leaf area and spike weight.
However medium values for genetic advance as percentage of mean was seen in grain filling period, harvest index, productive tillers per plant and plant height. The estimates of genetic advance help in understanding the type of gene action involved in the expression of various polygenic characters. High values of genetic advance are indicative of additive gene action where as low values are indicative of nonadditive gene action. Accordingly, Heritability and genetic advance are important selection parameters. The estimate of genetic advance is more useful as a selection tool when considered jointly with heritability estimates (Johnson et al., 
1955). High heritability associated with high genetic advance as percent of mean were observed for grain yield, test weight, grains per spike, spikelets per spike, spike weight, spike length, peduncle length and flag leaf areaindicating substantial contribution of additive gene action in the expression of the characters and selection may be effective. Upadhyay et al. (2020) reported similar findings for days to heading and plant height. Tiwari et al.(2017), Rajput (2018)also observed high heritability and high genetic advance as percent of mean for the traits canopy temperature index, harvest index, spike length, grains per spike, test weight, grain yield per plant, tillers per plant, 1st inter-node

\section{REFERENCES}

Allard, R.W. (1960) Principle of Plant Breeding. John Wiley and sons New York pg 185

Arya, V.K., Singh, J., Kumar, L., Kumar, R., Kumar, P., and Chand, P. (2017) Genetic variability and diversity analysis for yield and its components in wheat (Triticum aestivum L.). Indian Journal of Agriculture Research $51(2): 128-134$.

Burton, G.W. and DeVane. E. H. (1953) Estimating heritability in all fescue (Festucaarundinacea) from replicated clonal material. Agronomy Journal 45: 478-481.

Choudhary, R.C., Sharma, R. and Kumar, M. (2015) Genetic variability, heritability and genetic advance in wheat under different normal and heat stressed environments. Electronic Journal of Plant Breeding 6(4):1082-1087.

Falconer, D.S. and Mackay, T.F.C. (1996) Introduction to Quantitative Genetics 4th Edition, Longman Group Ltd., London

Johnson, H.W., Robinson, H.F. and Comstock, R.F. (1955) Estimates of genetic and environmental variability in soybean Agronomy Journal 47: 314-318.

Kumari, PritiNitish De, Anand Kumar and Anjali Kumari (2020) Genetic Variability, Correlation and Path coefficient analysis for Yield and Quality traits in Wheat (Triticumaestivum L.). International Journal of Current Microbiology and Applied Sciences 9(01): 826-832.

Mohammadi, S.A., and Prasanna, B.M. (2003) Analysis of genetic diversity in crop plants: salient tools and considerations. Crop Science 43:1235-1248.

Nishant, A.B, Arun, B., and Mishra. V.K. (2018) Genetic Variability, Heritability and length, weight of spike per plant, weight of grains per spike, biological yield and plant height, indicating that these characters are governed by additive gene effects and direct selection for these traits would be more effective for desired genetic improvement. The high heritability values coupled with high genetic advance were recorded for traits like Grain yield, grains per spike, spike length, peduncle length, test weight, spikelets per spike, flag leaf area and spike weight indicating that these characters are governed by additive gene effects and direct selection for these traits would be more effective for desired genetic improvement.

Correlation Study of Physiological and Yield Traits in Relation to Heat Tolerance in Wheat (Triticum aestivum L.). Biomed Journal Science and Technology Research 2(1): 2112-2116.

Panse, V. G. and Sukhatme P. V., (1967) Statistical method for agricultural workers (2nd Ed. ICAR, New Delhi: 381.

Rajput, R.S. (2018) Correlation path analysis heritability and genetic advance for morphological character on bread wheat (Triticumaestivum L.). Journal of Pharmacognosy and Phyto chemistry 7(2).107-112.

Robinson, H. F., Comstock, R. E. and Harvey, P. $H$. (1949) Estimation of heritability and the degree of dominance in corn. Agronomy Journal 41: 353-359.

Tiwari Akansha, Mishra D.K. and Shukla R.S. (2017) Genetic analysis of yield components an physiological Characters under changing climate in wheat. International Journal of Current Microbiology and Applied Science 6(9): 3525-3530.

Upadhyay, P., Krishna, S., Thakur, P., Agrawal, N., Yadav, P., Prasad, L.C. and Mishra V.K. (2020) Identification of genetic variability and diversity in selected wheat (Triticum aestivum L.) germplasm under three different dates of sowing. Journal of Pharmacognosy and Phytochemistry 9(2): 82-86.

Upasna Mishra, Sharma, A.K. and Shailja Chauhan (2019) Genetic variability, heritability and genetic advance in bread wheat (Triticum aestivum L.) International Journal of Current Microbiology and Applied Sciences 8 (07): 2311-2315. 